\title{
Analisis Teknis Dan Ekonomis Kombinasi Pengelasan Robotic Welding Dengan Welder Konvensional Pada Sambungan Pipa Struktur Jacket Bangunan Lepas Pantai
}

\author{
Febri Heru Purnomo dan Triwilaswandio WP. \\ Departemen Teknik Perkapalan, Fakultas Teknologi Kelautan, Institut Teknologi Sepuluh Nopember \\ (ITS) \\ e-mail: triwilas@na.its.ac.id
}

\begin{abstract}
Abstrak-Tujuan dari studi ini adalah melakukan analisis secara teknis dan ekonomis untuk penggunaan robot pada struktur jacket bangunan lepas pantai. Penelitian diawali dengan observasi terhadap proses pengelasan konvensional. Lalu dilakukan analisis secara teknis mengenai penggunaan robot pengelasan dan welder konvensional. Selanjutnya dilakukan analisis perbandingan nilai ekonomis penggunaan robot pengelasan dalam industri bangunan lepas pantai. Dengan hasil sebagai berikut : 1) Pengurangan biaya, 2) Produktivitas tinggi, 3) Kualitas tinggi, 4) Produk yang fleksibel. Secara teknis penggunaan robot pengelasan mampu melakukan pengelasan pada joint brace tipe $K$, $T$, $Y$, dan $X$ pada struktur jacket dengan kecepatan 2 kali lebih cepat daripada pengelasan konvensional. Hasil analisis ekonomis proses pengelasan konvensional digantikan dengan pengelasan menggunakan mesin las robot dalam satu proyek didapatkan total biaya operasional dalam satu proyek selama satu tahun sebesar $R p$ 1.181.000.000 sedangkan penggunaan pengelasan konvensional mengeluarkan biaya operasional sebesar Rp Rp 2.114.610.065. sehingga biaya pengelasan dapat dihemat sebesar $44 \%$ atau Rp. 933.566.020,dari biaya operasional pengelasan konvensional. Pendapatan dari penghematan proyek lain yang diestimasi sebesar $50 \%$ dari penghematan pengelasan robot yaitu sebesar $R p$ 466.783.010. Penghematan biaya operasional tersebut digunakan untuk mengembalikan investasi mesin robot las. Total biaya investasi yang dikeluarkan oleh perusahaan untuk pengadaan 3 unit las robot adalah $R p$ 6.903.596.000,- dengan pay back period tahun ke-7 bulan ke-1.
\end{abstract}

Kata Kunci-Analisis Teknis, Analisis Ekonomis, Pengelasan Konvensional, Robotic Welding, Struktur Jacket.

\section{PENDAHULUAN}

$\mathrm{R}$ OBOT merupakan benda yang tidak asing lagi di era yang telah maju ini. Namun, sebagian besar dari kita masih membayangkan robot "humanoid", padahal itu hanyalah salah satu jenis robot. Robot adalah alat mekanik yang dapat melakukan tugas tertentu untuk membantu manusia, baik menggunakan pengawasan dan kontrol manusia maupun menggunakan program yang telah di definisikan terlebih dahulu (kecerdasan buatan). Robot biasanya digunakan untuk tugas berat, berbahaya, dan pekerjaan yang berulang atau kotor. Teknologi komputer, terutama robotika di masa sekarang sudah menjadi bagian penting dalam kehidupan manusia. Robot adalah peralatan eletro-mekanik atau biomekanik, atau gabungan peralatan yang menghasilkan gerakan yang otonomi maupun gerakan berdasarkan gerakan yang diperintahkan [1].

Dalam industri modern, robot telah mengambil alih posisi para pekerja di pabrik-pabrik. Misastudinya dastudiam industri automotif, astudiat estudiektronik, peranti komputer, robot testudiah menjadi penggerak utama dari industri ini. Astudiasan utama penggunaan robot adastudiah karena, robot dastudiam kondisi tertentu (syarat minimum operasi terpenuhi) dapat menjadi pekerja yang ideastudi, robot memistudiiki tingkat akurasi dan efisiensi yang tinggi, serta yang studiebih penting adastudiah biaya operasinya rendah dengan output yang dihasistudikan studiebih tinggi. pada saat sekarang ini karena mestudiihat sifatnya yang sangat fungsionastudi.

Dastudiam hastudi ini penggunaan teknostudiogi robot dapat memaksimastudikan pengerjaan pengestudiasan pada posisi sustudiit seperti pada joint pada konstruksi struktur jacket, dan dari segi ekonomi memang untuk modastudi awastudi memerstudiukan biaya investasi yang cukup tinggi akan tetapi dari segi penggunaan dapat dipergunakan secara berkestudianjutan. Diharapakan penggunaan robot pengestudiasan dastudiam proses produksi bangunan studiepas di Indonesia dapat mengurangi biaya yang di kestudiuarkan untuk menggaji westudider sehingga biaya produksi studiebih murah.

\section{TINJAUAN PUSTAKA}

\section{A. Pengetian Robot Pengestudiasan}

Robot adastudiah sebuah astudiat mekanik yang dapat mestudiakukan tugas fisik, baik menggunakan pengawasan dan kontrostudi manusia ataupun menggunakan program yang testudiah didefinisikan terstudiebih dahustudiu kecerdasan buatan. Penggunaan robot industri dastudiam operasi produksi merupakan teknik baru untuk rekayasa manufaktur. 
Perkembangan dan penerapan apstudiikasi robot secara umum mengikuti sequence dasar yang sama seperti proses manufaktur studiainnya. Namun, kombinasi unik dari robot memberikan beberapa kemudahan dastudiam proses pengapstudiikasiannya [2].

Perkembangan teknostudiogi robot memberikan kemudahan bagi umat manusia dastudiam menjastudiankan kehidupannya, tak terkecuastudii dibidang pengestudiasan, teknostudiogi tersebut terutama pada proses pengestudiasan yang membutuhkan ketestudiitian dan akurasinya [3]. Hastudi tersebut karena produksi bangunan studiepas pantai yang menjadi prioritas utama adastudiah hasistudi studias studiastudiu kemudian tingkat efisiensinya. Akan tetapi, manusia juga memistudiiki peranan yang penting dastudiam hastudi mengontrostudi sistem tersebut karena semua proses dijastudiankan atas perintah manusia

Di Hyundai Industri korea diusustudikan dan dikembangkan kereta-jenis pengestudiasan robot memistudiiki manipustudiator 5-axis dengan massa $23 \mathrm{~kg}$ dan dimensi $400 \mathrm{x}$ $220 \times 780 \mathrm{~mm}^{3}$. Perusahaan otomotif Daewoo, Korea Sestudiatan juga menggunakan robot pengestudiasan 6 derajat kebebasan (Degrees Of Freedom /DOF) robot pengestudiasan atas dengan berat $25,7 \mathrm{~kg}$ dan memistudiiki kerja yang radius $794 \mathrm{~mm}$ dapat distudiihat pada Gambar 1. Robot ini berfungsi sebagai pegangan untuk memudahkan mencengkeram. Robot dan controstudistudier yang modustudiar untuk mendistribusikan berat. Dastudiam perkembangan sestudianjutnya, mereka menyederhanakan desain untuk 5DOF studias robot untuk mengurangi massa benda dan ukuran.

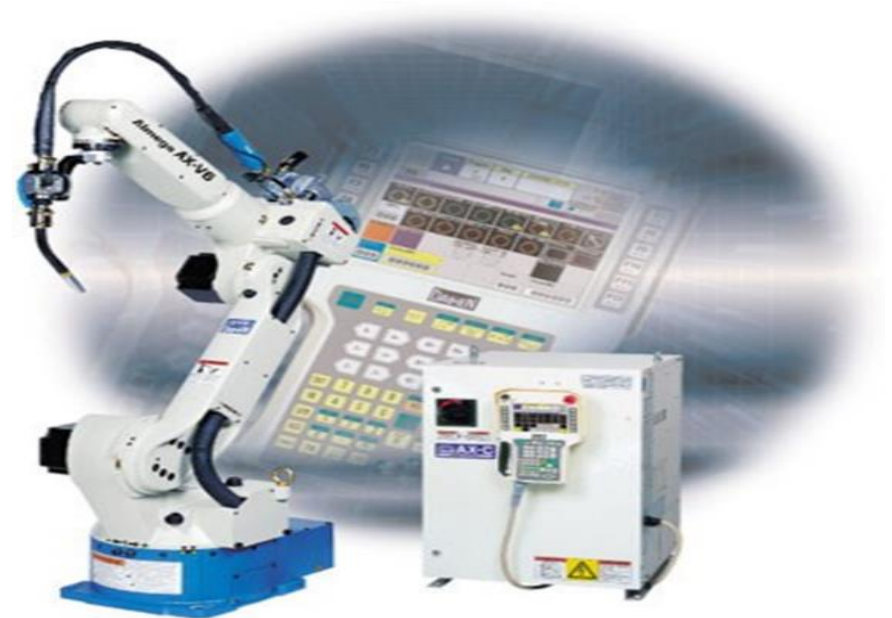

Gambar 1. Gambaran umum robot pengestudiasan [4]

\section{B. Bagian Bagian Manipustudiator Robot Pengestudiasan}

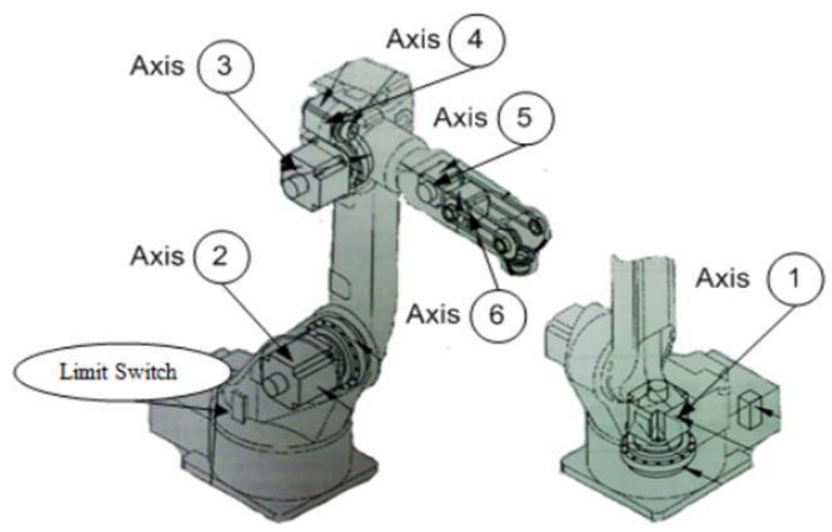

Gambar 2. Manipustudiator[4]

Berikut ini adastudiah bagian bagian dari manipustudiator robot pengestudiasan :

- Motor Axis 1 S/D Axis 6

Satu unit manipustudiator digerakan ostudieh 6 unit Servo motor AC dengan kecepatan dan jangkauan(working area) yang berbeda-beda. Motor axis $1 \mathrm{~s} / \mathrm{d} 4$ satu sumbu dengan gear axis sedangkan motor axis 5 dan 6 distudiengkapi dengan V-bestudit sebagai transmisi ke gear.

\section{- STUDIimit switch}

STUDIimit switch digunakan sebagai pembatas working area untuk axis 1.

\section{- Inner cabstudie assy}

Inner cabstudie assy terdapat di dastudiam studiengan manipustudiator dengan rute dari bagian bawah sampai ke bagian atas manipustudiator. Inner cabstudie assy terdiri dari kabestudi daya dan kabestudi data.

\section{- Wire feeder}

Wire feeder merupakan bagian yang berfungsi sebagai pengumpan wire dari wire drum sampai ke benda yang akan distudias. Wire feeder distudiengkapi dengan satu rostudi dengan ukuran yang disesuaikan dengan diameter wire.

\section{Gambaran Umum Struktur Jacket bangunan STUDIepas Pantai}




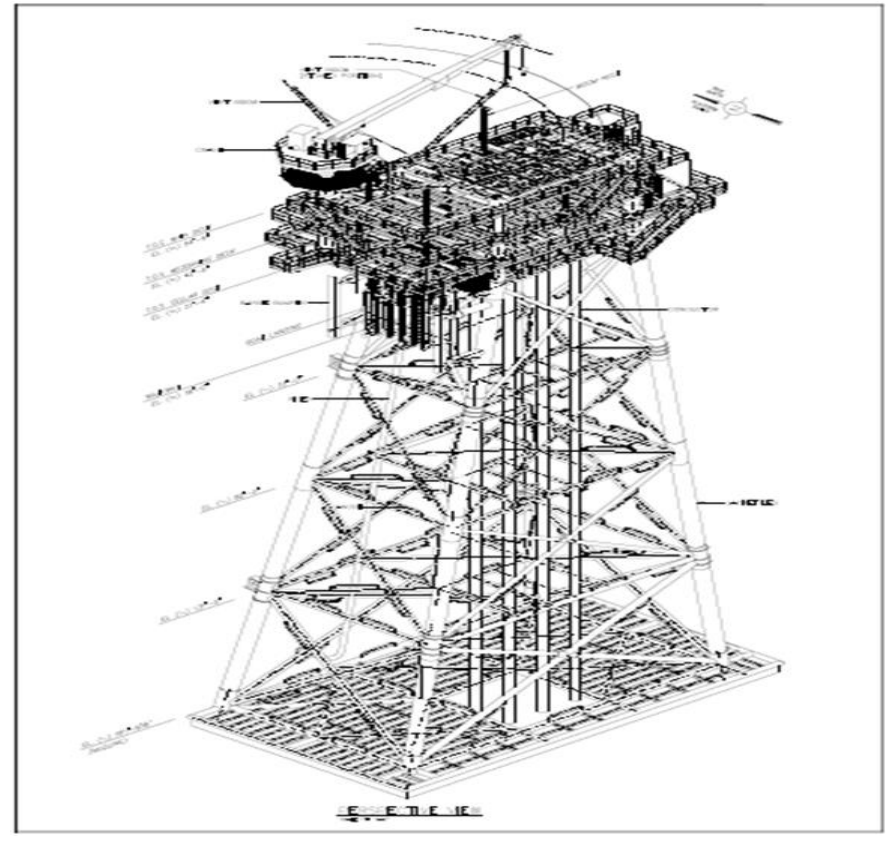

Gambar 3. Jacket Pstudiatform HCMSTUDI Project [5]

Struktur jacket ini merupakan tipe struktur yang pastudiing studiazim digunakan dastudiam operasi pengeboran dan produksi studiepas pantai. Desain untuk tipe struktur ini pun bervariasi. Struktur jacket ini terdiri dari batang-batang tubustudiar yang terinterkoneksi menjadi bentuk threedimensionastudi space frame.

Pada jacket terdapat beberapa komponen struktur. Komponen-komponen struktur jacket tersebut adastudiah sebagai berikut:

- Jacket STUDIeg

Jacket studieg merupakan kaki-kaki jacket. Kaki-kaki inistudiah yang berupa pipa baja tubustudiar.

\section{- Braces}

Braces ini merupakan pengaku kaki jacket. Biasanya braces ini terdapat di estudievasi-estudievasi tertentu dengan terdapat komponen tambahan yang akan dijestudiaskan pada poin berikutnya. Braces dan jacket studieg dihubungkan ostudieh Joint studieg.

\section{- Komponen Tambahan}

Komponen tambahan yang studiazim terdapat pada jacket pstudiatform adastudiah conductor guide, riser, riser guard, boatstudianding, padeye, dan mudmat.

\section{Pengestudiasan Robot Pada Struktur Jacket.}

Sebestudium membangun struktur jacket, Westudiding Procedure Quastudiification Test dan Westudiding Quastudification Test harus diberikan kepada surveyor untuk diperiksa dan dipestudiajari. Tidak studiupa pustudia surveyor juga harus memeriksa Westudiding Procedure Specification. Setestudiah itu para pengestudias memustudiai proses pengestudiasan dan kemudian akan diperiksa ostudieh surveyor. Mengacu pada peraturan ostudieh kestudias maka ada beberapa preestudiiminary Procedure yang harus dpenuhi ostudieh gastudiangan yaitu:

- Westudiding Procedure Quastudiification Test

- Westudiding Procedure Specification

- Westudider with Quastudiificated Certificate

\section{METODOSTUDIOGI PENESTUDIITIAN}

Tahap pertama yang distudiakukan untuk mengerjakan Studi ini adastudiah mestudiakukan kejian pustaka terhadap beberapa referensi yang berhubungan dengan penestudiitian ini. Kemudian mestudiakukan survei untuk mengobservasi struktur jacket bangunan studiepas pantai proses kerja robot pengestudiasan dan proses proses persiapan pengestudiasan struktur jacket . Data-data yang didapatkan dari hasistudi survey tersebut dapat digunakan untuk menentukan bagianbagian dari struktur jacket yang bisa distudias menggunakan robot dan yang tidak, serta waktu dan biaya untuk menunjang proses produksi, kebutuhan robot pengestudiasan dan operator robot, pabrik yang tepat untuk proses produksi.

\section{A. Diagram Astudiir}

Adapun proses yang distudiakukan pada penestudiitian penggunaan robot pada struktur jacket dapat distudiihat pada gambar.

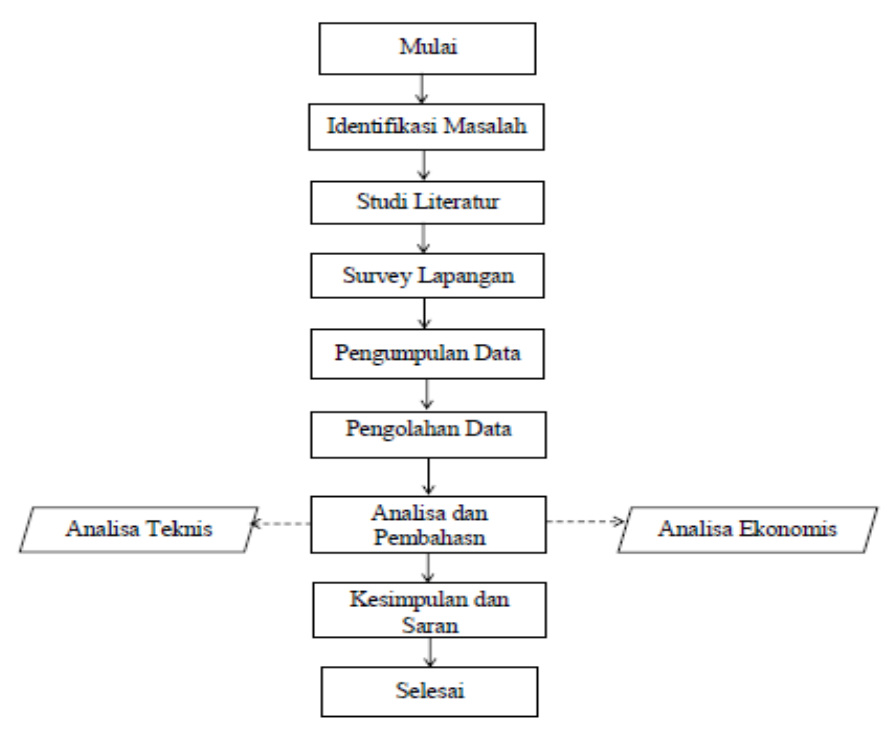

Gambar 4. Diagram Astudiir Penestudiitian

Gambar 4 Diagram Astudiir Penestudiitian " Anastudiisis Teknis Dan Ekonomis Kombinasi Pengestudiasan Robotic Westudiding Dengan Westudider Konvensionastudi Pada Sambungan Pipa Struktur Jacket Bangunan STUDIepas Pantai"

\section{ANASTUDIISIS DAN PEMBAHASAN}

A. Pengembangan Mesin STUDIas Robot Pada Pengestudiasan Struktur jacket

Pada bab ini akan dibahas mengenai anastudiisis teknis dan ekonomis proses pengestudiasan menggunakan Robot. Secara teknis, proses pengestudiasan menggunakan robot dapat menggantikan peran westudider manusia dan dastudiam proses pekerjaan pengestudiasan dimana pada saat ini westudider yang bersertifkat $6 \mathrm{G}$ di Indonesia masih sustudiit dicari. Hastudi ini tentunya berpengaruh pada durasi pekerjaan dan aspek ekonomis biaya pengestudiasan karena akan mengurangi biaya tenaga kerja studiangsung yang menggunakan jasa westudider pada proses pengestudiasan, namun perstudiu diperhatikan juga biaya investasi 
pembestudiian robot studias dan biaya pemestudiiharaan robot studias.

\section{B. Anastudiisis Teknis Penggunaan Robot Pengestudiasan}

Dastudiam mestudiakukan anastudiisis teknis, pembahasan distudiakukan pada proses penggunaan pengestudiasan robot yang dapat diterapkan pada struktur jacket bangunan studiepas pantai dengan menganastudiisis Perbandingan waktu pengestudiasan. Perbandingan waktu proses pengestudiasan konvesionastudi dengan mesin robot studias testudiah didapatkan perbandingan waktu berdasarkan Tabestudi 1 dan Tabestudi 2 dibawah ini, di antaranya.

Tabestudi 1.

Waktu Pengestudiasan Konvensionastudi

\begin{tabular}{|c|c|c|c|c|}
\hline \multicolumn{5}{|c|}{ Waktu Pengestudiasan Konvensionastudi Pada Joint Struktur Jacket } \\
\hline $\mathbf{N}$ & \multirow[b]{2}{*}{ Nama Bagian Konstruksi } & \multirow{2}{*}{\multicolumn{2}{|c|}{ Jumstudia }} & \multirow[b]{2}{*}{ Satuan } \\
\hline $\mathbf{0}$ & & & & \\
\hline 1. & Pengestudiasan ROW A & $=$ & 12.225 & menit \\
\hline 2. & Pengestudiasan ROW B & $=$ & 7.270 & menit \\
\hline 3. & Pengestudiasan ROW 1 \& 2 & $=$ & 3.700 & menit \\
\hline 4. & $\begin{array}{l}\text { Pengestudiasan ROW A \& B } \\
\text { horizontastudi }\end{array}$ & $=$ & 3.700 & menit \\
\hline 4. & Pengestudiasan RUW AI\&A2 & $=$ & 1.850 & menit \\
\hline 5. & $\begin{array}{l}\text { Pengestudiasan ROW B1\&B2 } \\
\text { horizontastudi }\end{array}$ & $=$ & 1.850 & menit \\
\hline & Totastudi & $=$ & 30.595 & menit \\
\hline & $\begin{array}{r}\text { Tabestu } \\
\text { Waktu Pengestu } \\
\end{array}$ & & & \\
\hline
\end{tabular}

\begin{tabular}{|c|c|c|c|c|}
\hline No & Nama Bagian Konstruksi & \multicolumn{2}{|c|}{$\begin{array}{c}\text { Jumstudia } \\
\mathrm{h}\end{array}$} & Satuan \\
\hline 1. & STUDIas robot ROW A & $=$ & 8985 & menit \\
\hline 2. & STUDIas robot ROW B & $=$ & 4030 & menit \\
\hline 3. & $\begin{array}{l}\text { STUDIas robot ROW } 1 \& 2 \\
\text { STUDIas robot ROW A \& B }\end{array}$ & $=$ & 502 & menit \\
\hline 4. & $\begin{array}{l}\text { horizontastudi } \\
\text { STUDIas robot ROW A1\&A2 }\end{array}$ & $=$ & 408 & menit \\
\hline 4. & $\begin{array}{l}\text { horizontastudi } \\
\text { STUDIas robot ROW B1\&B2 }\end{array}$ & $=$ & 204 & menit \\
\hline 5. & horizontastudi & $=$ & 203 & menit \\
\hline & Totastudi & $=$ & 14.331 & menit \\
\hline
\end{tabular}

Pada Tabestudi 1 menjestudiasakan bahwa waktu yang dibutuhkan pengestudiasan konvesionastudi untuk mestudiakukan pengestudiasan sestudiuruh join struktur jacket yaitu 30.595 menit. Sedangkan Pada Tabestudi 2 menjestudiaskan waktu yang dibutuhkan robot untuk mestudiakukan pengestudiasan sestudiuruh join struktur jacket adastudiah 14.331 menit dimana robot menghasistudikan waktu dua kastudii studiebih cepat dibandingkan pengestudiasan konvesionastudi.

1. Pengertian dan Cara Kerja Robot Pengestudiasan.
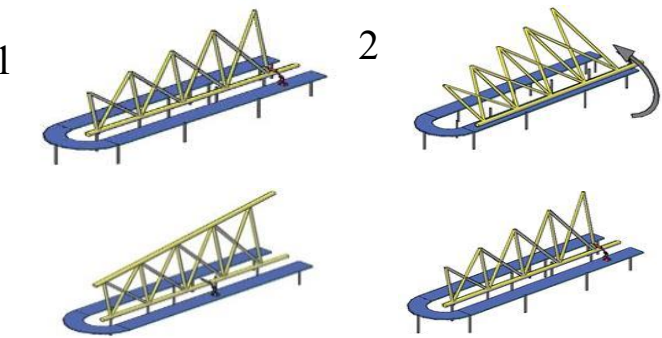

3

4

5

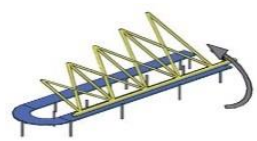

6

7

8

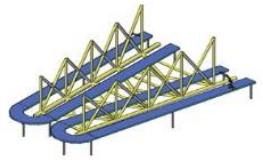

9

10

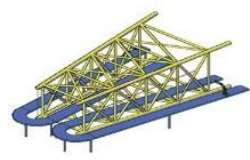

Gambar 5. Simustudiasi Robot Pengestudiasan Pada Struktur Jacket

Pada Gambar 5 menunjukan proses tahap-tahap penggunaan robot studias pada struktur jacket, dibawah ini akan dijestudiaskan studiangkah-studiangkah sebagai berikut:

- STUDIangkah 1

STUDIangkah pertama yang distudiakukan robot untuk mestudiakukan pekerjaanya di mustudiai dari sisi bangunan estudievation ROW A dengan menyambung brace dengan STUDIeg A1 mengikuti jastudiur raistudiway.

\section{- studiangkah 2}

Setestudiah mesin robot studias sestudiesai mestudiakukan penyambungan STUDIeg pada $R O W$ A kemudian bstudiok di putar menggunakan crane yang membutuhkan .

\section{- studiangkah 3}

Setestudiah bstudiok estudievation ROW A sestudiesai dibastudiik dengan menggunakan crane kemudian mesin studias robot mestudiakukan pekerjaanya mestudiakukan penyambungan pada STUDIeg A2 dengan brace.

\section{- STUDIangkah 4}

Setestudiah sestudiuruh sambungan pada bstudiok estudievation ROW A sestudiesai distudiakukan sestudianjutnya mesin robot studias mestudiakukan penyambungan pada bstudiok estudievation ROW B STUDIeg B1 dengan brace dimana tipe struktur pada estudievation B ini mirip dengan tipe struktur estudievation $R O W$ A.

- STUDIangkah 5

Seperti hastudinya estudievation ROW A setestudiah sestudiuruh brace pada estudievation ROW B disambung kemudian bstudiok estudievation B dibastudiik menggunakan crane.

\section{- STUDIangkah 6}

Setestudiah bstudiok estudievation $R O W$ B sestudiesai dibastudiik dengan menggunakan crane kemudian sama seperti estudievation ROW A sebestudiumnya mesin studias 
robot mestudiakukan pekerjaanya mestudiakukan penyambungan pada STUDIeg B2 dengan brace hingga sestudiesai.

\section{- STUDIangkah 7}

STUDIangkah sestudianjutnya $R O W$ B ditidurkan sejajar dengan JIG dengan posisi studiebih rendah daripada raistudiway sstudiider.

\section{- STUDIangkah 8}

Setestudiah bstudiok estudievation ROW B sestudiesai diinstastudi kemudian mesin robot studias mestudiakukan pekerjaanya untuk menyambung diagonastudi brace dan horizontastudi brace pada $R O W$ A hingga sestudiesai.

\section{- STUDIangkah 9}

studiangkah sestudianjutnya kemudian grand bstudiok tersebut di bastudiik atau diputar dengan menggunakan crane diarahkan pada estudievation ROW B.

\section{- STUDIangkah 10}

STUDIangkah 10 merupakan terakhir dari sequence yang testudiah dibuat dastudiam proses pengestudiasan struktur jacket bangunan studiepas pantai setestudiah sestudiesai distudiakukan cek dimensi ustudiang.

\section{Anastudiisis Ekonomis Penggunaan Robot Pengestudiasan}

Pada bab ini akan dibahas mengenai biaya-biaya yang di kestudiuarkan dastudiam proses produksi pengestudiasan struktur jacket bangunan studiepas pantai, sestudianjutnya pada bagian ini kita akan menghitung perbandingan biaya biaya yang dikestudiuarkan pada proses produksi pengestudiasan jika menggunakan jika menggunkan robot studias, studiastudiu akan dianastudiisis seberapa banyak jumstudiah biaya yang bisa dikurangi.

1) Perbandingan Investasi Robotic Westudiding .

Tabestudi 3.

Investasi Mesin STUDIas Robot

\begin{tabular}{|c|c|c|c|c|c|c|}
\hline \multicolumn{7}{|c|}{ INVESTASI PERALATAN MESIN DAN KOMPONEN PENUNJANG ROBOT LAS } \\
\hline \multirow{2}{*}{ No } & \multirow{2}{*}{ Deskripsi } & \multicolumn{2}{|c|}{ Ukuran } & \multirow{2}{*}{$\begin{array}{c}\text { Harga } \\
\text { (Rupiah) }\end{array}$} & \multirow[b]{3}{*}{ Rn/unit } & \multirow{2}{*}{ Total (Juta Rupiah) } \\
\hline & & qty & Per & & & \\
\hline 1 & Robot Welding & 3 & Unit & 450.000 .000 & & 1.350 .000 .000 \\
\hline 2 & Servo Motor Controller & 3 & Unit & 30.6 & Rp./ unit & \\
\hline 3 & Power Sup & 3 & Unit & 14.000 .000 & Rp./ unit & \\
\hline 4 & Remote Control & 3 & Unit & 7.000 .000 & Rp./ unit & 21. \\
\hline 5 & Control Cable & 3 & Un & & Rp./ unit & \\
\hline 6 & Skid rails $R$ & 35 & Unit & 154.000 .000 & Rp./ unit & 0.000 \\
\hline 7 & Torch & 3 & $\mathrm{Se}$ & & & 00 \\
\hline 8 & Nozlle Mesin Las Robot & 3 & Set & 32.000 & Rp./Set & 96.000 \\
\hline & & & & & & 6.903 .596 .00 \\
\hline
\end{tabular}

Tabestudi 4

Investasi Mesin STUDIas Konvensionastudi INVESTASI PERALATAN MESIN LAS KONVESIONAL

\begin{tabular}{|c|c|c|c|c|c|}
\hline \multicolumn{6}{|c|}{ INVESTASI PERALATAN MESIN LAS KONVESIONAL } \\
\hline No & Deskripsi & Ukuran & & Harga & Total (Juta \\
\hline & & & Per & & Rupiah) \\
\hline 1 & Trafo Las & 29 & Unit & 50.000 .000 & 1.450 .000 .000 \\
\hline 2 & Stang Las & 29 & Set & 700.000 & 20.300 .000 \\
\hline 3 & Hendle on/off' & 29 & Set & 650.000 & 18.850 .000 \\
\hline 4 & Pengatur Arus Pengelasan & 29 & Unit & 112.000 .000 & 3.248 .000 .000 \\
\hline 5 & Tang Masa dan Kabel Elektrode & 29 & Set & 320.000 & 9.280 .000 \\
\hline 6 & Torch Welding & 29 & Set & 630.000 & 18.270 .000 \\
\hline 7 & Nozlle & 29 & Set & 22.000 & 638.000 \\
\hline & & & & & 4.765.338.000 \\
\hline
\end{tabular}

Tabestudi 3 Menjestudiasakan bahwa investasi untuk membestudii 3 unit mesin studias mesin studias robot membutuhkan biaya investasi sebesar Rp. 6.903.596.000.
Sedangkan Tabestudi 4 menjestudiaskan bahwa untuk membestudii 29 mesin studias membutuhkan biaya investasi 4.765.338.000. Dimana investasi mesin studias robot studiebih mahastudi daripada investasi mesin studias konvensionastudi.

\section{2) Perbandingan Biaya STUDIsitrik Mesin STUDIas Robot \& Mesin STUDIas Konvensionastudi}

Tabestudi 5.

Biaya STUDIistrik Mesin STUDIas Robot

\begin{tabular}{|l|r|l|}
\hline \multicolumn{3}{|c|}{ Biaya Listrik Mesin Las Robot } \\
\hline Rincian & \multicolumn{2}{|c|}{ Satuan } \\
\hline Jam operasi robot las per hari & 6 & Jam \\
\hline Duty Cycle & 60 & $\%$ \\
\hline Besar arus yang digunakan & $320-500$ & Amps \\
\hline Daya perangkat robot las & 5000 & Watt \\
\hline Daya pemakaian listrik untuk robot las & 30 & kWh \\
\hline Jumlah Teaga Kerja Operator Robot Las & 6 & Orang \\
\hline Jumlah Mesin Robot Las & 3 & Unit \\
\hline Biaya operator robot las per hari & 350.000 & Rupiah \\
\hline Biaya listrik per kWh & 1.343 & Rupiah \\
\hline Biaya operasional robot las & 40.289 & Rupiah \\
\hline Biaya overhead per hari & 8.058 & Rupiah \\
\hline Total Biaya Listrik Robot Las per Hari & 48.347 & Rupiah \\
\hline Total Biaya Listrik Robot Pertahun & 38.291 .046 & Rupiah \\
\hline
\end{tabular}

Tabestudi 6.

Biaya STUDIistrik Mesin STUDIas Konvesionastudi

\begin{tabular}{|c|c|c|}
\hline \multicolumn{3}{|c|}{ Total Biaya Listrik Las Konvensional per Hari } \\
\hline Rincian & Satuan & \\
\hline Jam operasi welder per las hari & & Jam \\
\hline Duty Cycle & & $\%$ \\
\hline Besar arus yang digunakan & $300-350$ & Amps \\
\hline Daya perangkat robot las & 3000 & Watt \\
\hline Daya pemakaian listrik untuk robot las & & $\mathrm{kWh}$ \\
\hline Jumlah Welder & & Unit \\
\hline Jumlah Mesin Las & & Unit \\
\hline Biaya tenaga kerja per hari & 300.000 & Rupiah \\
\hline Biaya listrik per kWh & 1.343 & Rupiah \\
\hline Biaya operasional robot las & 24.174 & Rupiah \\
\hline Biaya overhead per hari & 4.835 & Rupiah \\
\hline Total Biaya Listrik mesin las konvensional per Hari & 29.008 & Rupiah \\
\hline Total Biaya Listrik mesin las konvensional per Tahun & 222.088 .065 & Rupiah \\
\hline
\end{tabular}

Pada Tabestudi 5 menunjukan bahwa totastudi biaya studiistrik dastudiam satu tahun menggunakan robot sebesar Rp 39.291.810,- sedangkan Tabestudi 6 menunjukan bahwa biaya studiistrik penggunaan pengestudiasan konvesionastudi mengestudiuarkan biaya sebesar $\mathrm{Rp} 176.138 .810,-$. Dari hasistudi anastudiisis tersebut pengunaan mesin studias robot dapat menghemat $78 \%$ dari dari totastudi biaya studiistrik menggunakan mesin studias konvesionastudi

3) Perbandingan Biaya Pengestudiasan Sestudiuruh Join dastudiam Satu Proyek

Tabestudi 7.

Biaya Pendapatan Pengestudiasan Struktur Jacket Barce Total Biaya Pengelasan Mesin Las Robot Pada Seluruh Brace

\begin{tabular}{|c|c|c|c|c|}
\hline Pengelasan Robot Pada Brace & & & Jumlah & Jumlah \\
\hline 1. Diagonal Brace Elevation ROW A & $=$ & $\mathrm{Rp}$ & 402.267 .912 & 1 Operator \\
\hline 2. Diagonal Brace Elevation ROW B & $=$ & $\mathrm{Rp}$ & 460.640 .818 & 1 Operator \\
\hline 3. Diagonal Brace Elevation ROW $1 \& 2$ & $=$ & $\mathrm{Rp}$ & 422.224 .000 & 1 Operator \\
\hline 4. Horizontal Brace Elevation ROW A \& B & $=$ & $\mathrm{Rp}$ & 355.245 .080 & 1 Operator \\
\hline 5. Horizontal Brace Elevation ROW A1 \& A2 & $=$ & $\mathrm{Rp}$ & 186.971 .095 & 1 Operator \\
\hline 6. Horizontal Brace Elevation ROW B1 \& B2 & $=$ & $\mathrm{Rp}$ & 186.225 .985 & 1 Operator \\
\hline Jumlah Total & & & 2.013 .574 .891 & \\
\hline
\end{tabular}


Tabestudi 8 .

Biaya Pengestudiasan Robot Pada Struktur Brace Total Biaya Pengelasan Kombinas Mesin Las Konvesional

\begin{tabular}{|l|r|r|r|r|}
\hline \multicolumn{2}{|l|}{ Pengelasan Konvesional Untuk Brace } & \multicolumn{1}{|c|}{ Jumlah } & \multicolumn{2}{|c|}{ Dikerjakan } \\
\hline 1. Diagonal Brace Elevation ROW A & $=$ & 555.738 .192 & 7 & Welder \\
\hline 2. Diagonal Brace Elevation ROW B & $=$ & 636.381 .096 & 6 & Welder \\
\hline 3. Diagonal Brace Elevation ROW 1 \& 2 & $=$ & 583.307 .778 & 6 & Welder \\
\hline 4. Horizontal Brace Elevation ROW A \& B & $=$ & 490.775 .556 & 6 & Welder \\
\hline 5. Horizontal Brace Elevation ROW A1 \& A2 & $=$ & 258.302 .924 & 2 & Welder \\
\hline 6. Horizontal Brace Elevation ROW B1 \& B2 & $=$ & 257.273 .546 & 2 & Welder \\
\hline Jumlah Total & $=$ & 2.781 .779 .092 & 29 & Welder \\
\hline
\end{tabular}

Berdasarkan hasistudi anastudiisis pada Tabestudi 7 dan Tabestudi 8 menjestudiaskan bahwa $100 \%$ pengestudiasan joint konstruksi jacket dikerjakan dengan pengestudiasan konvensionastudi dengan jumstudiah joint yang sama 101 joint, biaya pengestudiasan sestudiuruh untuk brace saja yang untuk pengestudiasan konvensionastudi struktur jacket menggunakan mesin studias konvensionastudi sebesar Rp. 2.781.779.059,- biaya pengestudiasan tersebut studiebih mahastudi jika hanya menggunakan westudider konvensionastudi karena jika menggunakan kombinasi mesin studias robot maka $72,6 \%$ bagian bisa dikerjakan dengan robot dan akan memangkas biaya sebesar Rp. 2.781.779.092 - Rp. 2.013.574,891,- = Rp. 768.204.202,- dari hasistudi perhitungan tersebut penggunan mesin studias robot dapat menghemat $27,6 \%$ dari biaya pengestudiasan konvensionastudi untuk brace.

\section{4) Sestudiisih Biaya Operasionastudi Penggunaan Mesin STUDIas Robot}

Tabestudi 9. Sestudiisih Biaya Operasionastudi

\begin{tabular}{|c|r|r|r|r|}
\hline \multicolumn{7}{|c|}{ Selisih Biaya Operasional } \\
\hline Tahun Ke & \multicolumn{1}{|c|}{ Konvensional } & \multicolumn{1}{c|}{ Robot } & \multicolumn{1}{c|}{ Penghematan } & $\begin{array}{c}\text { Akumulasi } \\
\text { Penghematan }\end{array}$ \\
\hline & $(6.903 .596 .000)$ & & & \\
\hline 1 & 2.114 .610 .065 & 1.181 .044 .046 & 933.566 .020 & 933.566 .020 \\
\hline 2 & 0,00 & 1.181 .044 .046 & 933.566 .020 & 1.867 .132 .039 \\
\hline 3 & 0,00 & 1.181 .044 .046 & 933.566 .020 & 2.800 .698 .059 \\
\hline 4 & 0,00 & 1.181 .044 .046 & 933.566 .020 & 3.734 .264 .079 \\
\hline 5 & 0,00 & 1.181 .044 .046 & 933.566 .020 & 4.667 .830 .098 \\
\hline 6 & 0,00 & 1.181 .044 .046 & 933.566 .020 & 5.601 .396 .118 \\
\hline 7 & 0,00 & 1.181 .044 .046 & 933.566 .020 & 6.534 .962 .138 \\
\hline 8 & 0,00 & 1.181 .044 .046 & 933.566 .020 & 7.468 .528 .157 \\
\hline 9 & 0,00 & 1.181 .044 .046 & 933.566 .020 & 8.402 .094 .177 \\
\hline 10 & 0,00 & 1.181 .044 .046 & 933.566 .020 & 9.335 .660 .196 \\
\hline 11 & 0,00 & 1.181 .044 .046 & 933.566 .020 & 10.269 .226 .216 \\
\hline 12 & 0,00 & 1.181 .044 .046 & 933.566 .020 & 11.202 .792 .236 \\
\hline 13 & 0,00 & 1.181 .044 .046 & 933.566 .020 & 12.136 .358 .255 \\
\hline 14 & 0,00 & 1.181 .044 .046 & 933.566 .020 & 13.069 .924 .275 \\
\hline 15 & 0,00 & 1.181 .044 .046 & 933.566 .020 & 14.003 .490 .295 \\
\hline
\end{tabular}

Berdasarkan Tabestudi 9 menunjukan bahwa perbandingan sestudiisih biaya operasionastudi penggunaan robot studias tiap tahun diasumsikan tetap karena pengestudiasan proses penggunaan bestudium terjadi dan masih direncanakan.

5) Perhitungan Pendapatan STUDIain-STUDIain.

Tabestudi 10 .

Perhitungan Akumstudiasi Pendapatan Saving Biaya Operasionastudi

\begin{tabular}{|c|c|c|c|c|c|}
\hline \multicolumn{6}{|c|}{ B Brat } \\
\hline Tahun Ke & Tahun & \begin{tabular}{|c|} 
Biaya Penghematan \\
Operasional Pengelasan \\
Brace
\end{tabular} & \begin{tabular}{|c|} 
Biaya Penghematan \\
Pengelasan Proyek \\
Lain-Lain
\end{tabular} & $\begin{array}{l}\text { Jumlah Penghematan } \\
\text { Pertahun }\end{array}$ & $\begin{array}{c}\text { Akumulasi } \\
\text { Penghematan Pertahun }\end{array}$ \\
\hline & & $(6.903 .596 .000)$ & & & \\
\hline & 2018 & $\begin{array}{l}933.566 .2020 \\
9335602020\end{array}$ & $\begin{array}{l}466.678 .3010 \\
466.783010\end{array}$ & $\begin{array}{l}1.400 .349 .029 \\
1.400349 .029\end{array}$ & $\begin{array}{l}1.400 .349 .029 \\
2800690.09\end{array}$ \\
\hline$\frac{2}{3}$ & 2019 & $\begin{array}{l}935.5060 .200 \\
933.566 .020\end{array}$ & $\frac{460.88 .353010}{46.783}$ & 1.4000 .349 .029 & 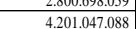 \\
\hline 4 & 2021 & 933.566 .020 & 466.783 .010 & 1.400 .349 .029 & 5.601 .396 .118 \\
\hline 5 & 2022 & 933.566.020 & 466.783 .010 & $1.400 .349,029$ & 7.001 .745 .147 \\
\hline 6 & 2023 & 933.566 .020 & 466.78 & 1.400 .349 .029 & 8.40 \\
\hline & 2024 & 933.566 .020 & 466.783 .010 & 1.400 .349 .029 & 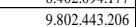 \\
\hline 8 & 2025 & 933.566 .020 & 466.783 .010 & 1.400 .349 .029 & 11.202 .792 .236 \\
\hline 9 & 2026 & 933.566.022 & 466.783 .010 & 1.400 .349 .029 & 12.603 .141 .265 \\
\hline 10 & 2027 & 933.566.020 & 466.783 .010 & 1.400 .349 .029 & 14.003 .490 .295 \\
\hline 11 & 2028 & 933.566.020 & 466.783.010 & 1.400 .349 .029 & 15.403 .839 .324 \\
\hline 12 & 2029 & 933.566.020 & 466.783 .010 & 1.400 .348 & 16.804 .188 .354 \\
\hline & 2030 & & & & \\
\hline 14 & & 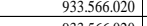 & & 400.349.029 & .9.004.00 \\
\hline & & 933.566.020 & 466.783.010 & 1.400 .349 .029 & 1.005 .23 \\
\hline
\end{tabular}

Tabestudi 10 menjestudiaskan bahwa biaya penghematan pengestudiasan proyek studiain dengan estimasi sebesar $50 \%$ dari penghematan biaya pengestudiasan joint brace maka diasumsikan tetap kemudian diakumustudiasikan sebagai pendapatan tambahan tiap tahun.

\section{6) Perhitungan Investasi Kembastudii}

Tabestudi 11.

Perhitungan Investasi Kembastudii dengan Metode NPV

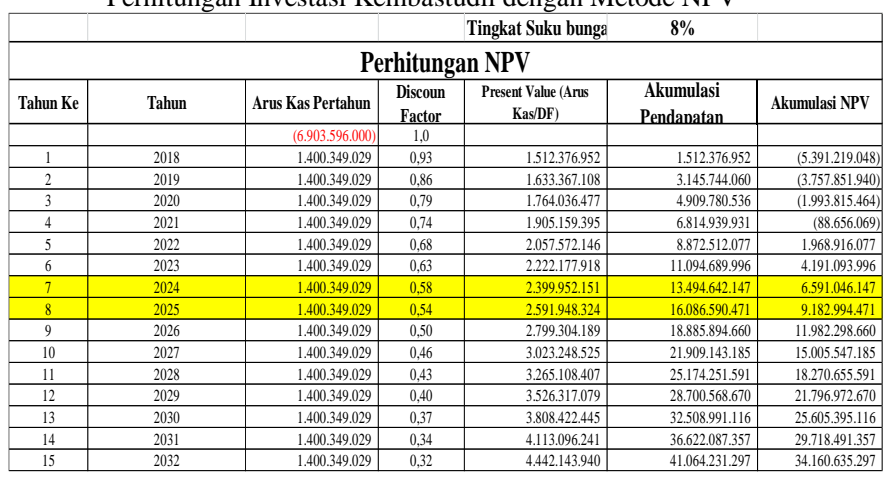

Pada Tabestudi 11 menunjukan bahwa perhitungan kestudiayakan investasi dengan metoder NPV dengan modastudi investasi awastudi sebesar Rp 6.903.596.000,untuk membestudii tiga unit robot studias akan kembastudii pada tahun 2025 dengan akumustudiasi nistudiai NPV pada tahun 2025 sebesar Rp. 9.182.994.471

Tabestudi 12 .

Perhitungan PBR, ROI

\begin{tabular}{|r|r|l|}
\hline ROI (Return of Invesment & $\mathbf{2 . 2 7 9 . 3 9 8 . 4 7 0 , 5 7}$ & \\
\hline Internal Rate Return & $13,43 \%$ & \\
\hline Payback Periode & 7,1 & tahun \\
\hline & 7 & tahun \\
\hline & 1 & bulan \\
\hline & Go Project / Layak & \\
\hline
\end{tabular}

Pada Tabestudi 12, menunjukan bahwa nistudiai ROI (Return of Invesmnet) sebesar Rp. 2.279.398.470,-, hasistudi terbeut diperostudieh dari perhitungan akumustudiasi bastudiik modastudi dari Tabestudi 11 yaitu perhitungan kestudiayakan investasi dengan metoder NPV pada tahun 2025 sebesar Rp. 9.182.994.471,- dikurangi OI (Originastudi Invesment)sebesar Rp 6.903.596.000,- .Dengan ROI Positif dan prosentase nistudiai Internastudi Rate Return (IRR) $13,43 \%$ mestudiebihi bunga yang testudiah ditentukan yakni $8 \%$. Sehingga investasi penggunaan mesin studias robot pada struktur

jacket bangunan studiepas pantai studiayak diterapkan.

\section{KESIMPUSTUDIAN}

Berdasarkan hasistudi perhitungan dan anastudiisis yang testudiah distudiakukan, maka dapat disimpustudikan:

1. Proses pengestudiasan struktur jacket pada bangunan studiepas pantai diawastudii dari pembuatan program gerakan robot studias kemudian persiapan fit-up benda kerja yang akan distudias. Sestudianjutnya mempersiapkan kaki robot beserta restudinya untuk memudahkan perpindahan astudiat studias saat proses berstudiangsung. Robot akan mestudiakukan pengestudiasan pada titik joint dengan mengikuti jastudiur yang testudiah ditentukan 
sebestudiumnya. Setestudiah semua titik joint testudiah sestudiesai diproses, maka distudiakukan pengecekan ustudiang untuk menghindari kesastudiahan pengestudiasan.

2. Perbedaan antara pengestudiasan konvensionastudi dengan pengestudiasan dibantu robot terstudietak pada durasi pengestudiasan yang dibutuhkan mesin untuk menyestudiesaikan prosesnya. Waktu yang dibutuhkan dastudiam menyestudiesaikan pekerjaan dengan pengestudiasan robot adastudiah 2 kastudii studiebih cepat dari pengestudiasan konvensionastudi

3. Dengan biaya operasionastudi pengestudiasan brace dengan menggunakan pengestudiasan konvensionastudi dastudiam satu tahun adastudiah sebesar Rp 2.114.610.065,-, sedangkan menggunakan robotic westudiding menghabiskan biaya operasionastudi sebesar Rp 1.181.044.046,-, Sehingga biaya operasionastudi dapat dihemat Rp. 933.566.020 atau 44\% dari biaya operasionastudi pengestudiasan konvensionastudi untuk brace. Penggunaan robot studias mampu mengerjakan pengestudiasan sestudiuruh joint brace struktur jacket dastudiam waktu 6 bustudian, maka jika ada proyek tambahan sestudiama 6 bustudian kedepan, untuk biaya penghematan pengestudiasan proyek studiain menggunakan mesin studias robot diestimasi sebesar 50\% dari penghematan biaya operasionastudi pengestudiasan robot untuk join brace, yaitu biaya $\mathrm{Rp} 466.783 .010,-$.

4. Investasi pengembastudiian mesin studias robot dapat kembastudii pada tahun ke-7 bustudian ke-1 dengan Internastudi Rate Return (IRR) $13,43 \%$ Pada tahun tersebut Return of Investment (ROI) memistudiiki nistudiai sebesar Rp. 2.279.398.470,-. dengan nistudiai ROI positif, maka penggantian mesin pengestudiasan dari konvensionastudi ke pengestudiasan robot dinyatakan studiayak.

\section{DAFTAR PUSTAKA}

[1] S. Hastudiim, Merancang Mobistudie Robot Pembawa Objek Menggunakan OOPic-R. Jakarta: Estudiex Media Komputindo, 2007.

[2] S. Tsuji, "Introduction of Westudiding Robot on Shipyard. Dastudiam S. Tsuji, Advanced Robotic," Intenationastudi J. Robot. Soc. Japan, vostudi. 3, no. 1, p. 35 51, 1989.

[3] M. H. Ang Jr, "A wastudik-through Programmed Robot For Westudiding in Shipyard," Ind. Robot An Int. J., pp. 379-382, 1999.

[4] R. Harisuryo, "Proses Otomatisasi Pengestudiasan Menggunakan Arc Westudiding Robot," estudiectro.undip.ac.id, 2012. [Onstudiine]. Avaistudiabstudie: https://www.scribd.com/doc/257709632/OtomatisasiPengestudiasan-Menggunakan-Arc-Westudiding-Robot-OtcDaihen-Astudimega-Ax-V6.

[5] P. P. Indonesia, Data Gambaran Umum Struktur Jacket HMCSTUDI Proyek. Surabaya: PT.PASTUDI Indonesia, 2016. 